\title{
Evaluating human capital obsolescence
}

Citation for published version (APA):

de Grip, A. (2006). Evaluating human capital obsolescence. Researchcentrum voor Onderwijs en Arbeidsmarkt, Faculteit der Economische Wetenschappen. ROA Working Papers No. 2E https://doi.org/10.26481/umarow.200602E

Document status and date:

Published: 01/01/2006

DOI:

10.26481/umarow.200602E

Document Version:

Publisher's PDF, also known as Version of record

\section{Please check the document version of this publication:}

- A submitted manuscript is the version of the article upon submission and before peer-review. There can be important differences between the submitted version and the official published version of record.

People interested in the research are advised to contact the author for the final version of the publication, or visit the DOI to the publisher's website.

- The final author version and the galley proof are versions of the publication after peer review.

- The final published version features the final layout of the paper including the volume, issue and page numbers.

Link to publication

\footnotetext{
General rights rights.

- You may freely distribute the URL identifying the publication in the public portal. please follow below link for the End User Agreement:

www.umlib.nl/taverne-license

Take down policy

If you believe that this document breaches copyright please contact us at:

repository@maastrichtuniversity.nl

providing details and we will investigate your claim.
}

Copyright and moral rights for the publications made accessible in the public portal are retained by the authors and/or other copyright owners and it is a condition of accessing publications that users recognise and abide by the legal requirements associated with these

- Users may download and print one copy of any publication from the public portal for the purpose of private study or research.

- You may not further distribute the material or use it for any profit-making activity or commercial gain

If the publication is distributed under the terms of Article $25 \mathrm{fa}$ of the Dutch Copyright Act, indicated by the "Taverne" license above, 


\section{Evaluating Human Capital Obsolescence}

ROA-W-2006/2E

Andries de Grip

This paper was funded by the EC and commissioned by the OECD, and presented at the joint EC-OECD Seminar on Human Capital and Labour Market Performance, Brussels, December 8, 2004.

Research Centre for Education and the Labour Market

Faculty of Economics and Business Administration Maastricht University

Maastricht, January 2006 
ISBN-10: 90-5321-430-5

ISBN-13: 978-5321-430-5

Sec06.014.doc 


\section{Contents}

Executive summary

1 Introduction

2 Causes of obsolescence of human capital

3 Measurement of human capital obsolescence

4 Evidence of human capital obsolescence $\quad 7$

4.1 Technical obsolescence $\quad 8$

$\begin{array}{ll}4.2 \text { Economic obsolescence } & 10\end{array}$

5 Sectors of industry with highest risks of human capital obsolescence 14

$6 \quad$ Life-long learning $\quad 18$

7 Training participation and risks of human capital obsolescence in the Netherlands

8 Conclusions and policy implications 



\section{Executive summary}

Obsolescence of human capital belongs to the heart of the economic challenge the Western economies face: to realize the transformation towards a knowledge-based society by means of lifelong learning. This holds the more for the EU Member States with their greying working populations and their need to increase labour market participation.

First a typology of the various possible causes of human capital obsolescence is given. Starting point is the distinction between the technical obsolescence that refers to the fact that workers for some reason may lose skills they had before, and economic obsolescence that affects the value of workers' human capital. Building on this, we distinguish five different kind of human capital obsolescence:

- the wear of skills due to aging, or illness that may be related to working conditions;

- the atrophy of skills due to insufficient use;

- job-specific obsolescence due to technological and organizational change;

- sector-specific obsolescence due to shifts in employment;

- firm-specific skills obsolescence due to displacement.

Then the different ways in which the obsolescence of human capital is measured are discussed: (1) objective method: testing; (2) subjective method: asking workers or their employers; (3) workers' wages; (4) the probability to lose employment. All four measures have their restrictions. The last two indirect methods have the advantage that they measure the labour market effects of skills obsolescence that are the main concern on human capital obsolescence in a knowledge economy: a lower productivity and a lower labour market participation. Although the labour market exit of workers that face skills obsolescence will be highly related to the benefits of early pensioning schemes and social security schemes on disablement, using this measure of skill obsolescence has the advantage that it measures the effects of skill obsolescence in the context of the prevailing labour market institutions, indicating that a worker's productivity in the labour market does no longer outweigh the benefits of not participating in the labour market.

Several studies indicate that all kinds of human capital obsolescence occur in practice. However, due to the limitations in the measurement of skill obsolescence, the results found can often be related to alternative explanations. However, among others it is interesting that some studies found that technological and organizational change decreases early exit from the labour market, as these workers continuously invest in lifelong learning.

Employers as well as workers may have less incentives to invest in training when workers face a wear of their skills due to heavy working conditions or substantial shifts in the sector structure of employment, because financial incentives to invest in retraining for a job in another sector of industry are often lacking.

Given the relevance of the topic, the literature on human capital obsolescence is remarkably limited. Obviously, this is due to the poor availability of adequate longitudinal data. More 
investments must be made in developing the statistics on the skills demanded in the labour market, the potential risks of human capital obsolescence, and the acquisition and deterioration of the human capital of the potential working population. This will contribute to the transparency of the labour market dynamics that may cause human capital obsolescence. At the moment not only governments are badly informed on the costs and benefits of life-long learning, also individuals often lack the information on the risks on human capital obsolescence they run in the various occupational fields and sectors of industry and the ways in which they can anticipate or react to these risks.

Furthermore, public policy in the field of working conditions and social security should be related to public policy in the field of education, career development and continuous vocational training. In a similar way public policy should take account of the interaction between human capital obsolescence and the labour market institutions related to the various routes of labour market exit. Although the 'Lisbon agenda' of the European Council offers a good framework for an integrated view on these different policy fields, there is still a long way to go.

Moreover, major decisions must be taken on the responsibilities of firms, individual workers and the government for the maintenance of human capital in relation to the potential risks of human capital obsolescence. Particularly for individual workers who are often challenged to stay 'employable' in the labour market, a consistent demarcation of their responsibilities for life-long learning is lacking, and proper incentives and financial facilities are missing. 


\section{Introduction}

Human resources are playing a central role in the knowledge economy that emerged in the Western world as the human capital embodied in both high-tech capital goods and the working population is a main determinant of the performance of individuals, organizations and national economies. Human resources stimulate technological change, whereas technological change stimulates the use of human resources. First, human capital is an important input factor in research \& development, which is in particular emphasized by endogeneous growth theory (e.g. Romer, 1990). This is called the research effect of human capital (Cörvers, 1999). Second, high-skilled workers are of crucial importance for the diffusion of new technologies in the various sectors of the economy (Bartel \& Lichtenberg, 1987). This is the diffusion effect of human capital.

Driven by the rapid developments in information and communication technology, technological developments increase the complexity of jobs in almost all sectors of the economy. In public policy the upgrading of skills demanded in the labour market is broadly recognized. The 'White Paper' on Growth, Competitiveness, Employment of the European Commission (1993) argues that a highly skilled labour force in the European Union is required to catch up in the technological race with other developed countries. The Lisbon 2000 strategic target of the European Council (2000) that Europe should "become the most competitive and dynamic knowledge-based society of the world" in 2010 emphasizes the importance of a highly skilled labour force for the competitive power of national economies.

Economic theory particularly focused on the causes of the upgrading process in the labour market in the 'trade versus technology' debate. Whereas e.g. Wood (1994) states that international specialisation is the driving force behind the increasing skill intensity of the economies in the Western world, many other authors see technological developments and in particular the diffusion of information technology as the main determinant of the increasing skill intensity (e.g. Autor, Katz \& Krueger, 1998 and Machin \& Van Reenen, 1998). Moreover, some authors argue that it is not merely the introduction of information technology that induces skill-biased technological change, but the combination of three related innovations: (1) information technology, complementary workplace reorganization and (3) the introduction of new products and services (cf. Caroli \& Van Reenen, 2001; Bresnahan et al., 2002).

Apart from the upgrading effect of the skill level demanded in the labour market, there can also be shifts in the type of skills demanded. This shift in the type of skills demanded in the labour market might be related to the shift in the occupational structure of employment. However, while occupational titles may remain steady the content of each occupation may alter, leading to changes in the skills required for an adequate performance in the job. Green et al. (2000) find that in particular problem-solving skills, communication and social skills and computing skills are becoming increasingly important in many jobs, whereas the market price of manual skills declines. These shifts in the skills demanded in many jobs can be related to the organizational changes that accompany the diffusion of ICT." Autor, Katz \& Krueger (1998) suggest that this in particular holds for the increasing demand for workers 
with both cognitive and relational skills, whereas Lindbeck \& Snower (2000) argue that in particular the shift from intensely specialized mass production towards modes of production that focus on tailor-made products requires more flexible and multi-skilled workers. Borghans \& Ter Weel (2003) found that the diffusion of ICT remarkably did not increase the value of workers' computer skills. Instead the diffusion of personal computers in the workplace increased the demand for general analytical skills.

\section{Obsolescence of human capital}

Both the upgrading of the skill level and the shifts in the type of skills demanded may deteriorate the skills workers acquired in the past. This refers to the notion of the half-life of a worker's human capital. This half-life of a worker's human capital can be described as "the time after completion of professional training when, because of new developments, practicing professionals have become roughly half as competent as they were upon graduation to meet the demands of their profession" (Dubin, 1972). However, the measurement of the obsolescence of human capital is far from straightforward and ranges from subjective judgements to more direct measurements of productivity (De Grip \& Van Loo, 2002).

Obsolescence of human capital probably belongs to the heart of the economic challenge the western economies face: to realize the transformation towards a knowledge-based society by means of lifelong learning. This holds the more for the EU Member States with their greying working populations. Particular for older workers whose skills are related to less recent vintages of human capital it is difficult to remain in the labour market. Moreover, older workers who face skill obsolescence may be reluctant to re-invest in their human capital, since the period over which they can amortize their training investment is shorter. With respect to the labour market participation of older workers the European Council has set itself two objectives for the Lisbon target year 2010:

- at least half of the population in the 55-64 age group should be employed;

- a five-year delay in the average age at which people withdraw from the labour market. (European Commission, 2003).

In this paper I will first discuss a typology of the various possible causes of human capital obsolescence (section 2). Then I will discuss the different ways in which the obsolescence of human capital can be measured (section 3 ). In section 4 I will discuss the evidence on skills obsolescence that exists in the literature. This literature review will be framed into the typology presented in section 2 and also be related to the different ways in which skill obsolescence can be measured. To give some indication to what extent the workers in the various sectors of industry might face skill obsolescence, I will present some empirical indicators of the potential risks of human capital obsolescence for the workers in the various sectors of industry in the Netherlands in section 5 . In section 6 I first discuss what kinds of learning or training activities could be remedies for the different kinds of human capital obsolescence, that were distinguished in section 2. In section 7 I will present some empirical evidence on training participation in the various sectors of industry in the Netherlands. Then I 
will discuss the training participation in the various sectors of industry in relation to the specific potential risks of human capital obsolescence in each sector. Moreover, the training participation of older workers will be briefly discussed In section 8 , I will conclude and discuss some policy issues.

\section{Causes of obsolescence of human capital}

It is important to distinguish between two different kinds of obsolescence of human capital, analogously to economic theory on the depreciation of physical capital: technical and economic obsolescence of human capital. Technical obsolescence of human capital affects the skills of a worker and refers to:

1. the wear of skills due to the natural aging process, injuries or illness, which may be related to the working conditions in a particular occupation or sector of industry, or

2. the atrophy of skills due to unemployment, career interruptions or as a result of specialisation.

Economic obsolescence of human capital affects the value of the human capital of workers and is caused by changes in the job or work environment. These changes in job content are usually related to technological and organizational change.

Table 1

Typology of the various kinds of human capital obsolescence

Type of skills obsolescence

Depreciation of human capital by:

Technical human capital obsolescence

- Wear

- Atrophy

Natural ageing process, illness, or injury

No or insufficient use of skills

Economic human capital obsolescence

- Job-specific human capital obsolescence

New skill requirements due to technological and organizational developments

- Sector-specific skills obsolescence

Shrinking employment in occupation or economic sector

- Firm-specific skills obsolescence

Displacement in sectors with stable employment

It is obvious that greying knowledge economies have to face both kinds of obsolescence of human capital. This addresses the need for lifelong learning in order to maintain the employability of the working population in the western economies. By studying human capital obsolescence from the broader perspective of both technical and economic skills obsolescence, an integrated framework is given for firms' human resource policies as well as public policies that aim to increase the participation and productivity of the potential labour force. 
Building on this distinction between technical and economic obsolescence of human capital, De Grip, Van Smoorenburg \& Borghans (1997) developed a typology of five different types of human capital obsolescence related to the cause of the obsolescence (see table 1).

\section{Technical human capital obsolescence}

Firstly, the depreciation of human capital may simply be caused by the wear of skills, resulting from the natural ageing process, injuries or illness. This kind of technical obsolescence may be related to physically or mentally demanding working conditions in the job where a worker is employed, as disablement can be seen as a particular form of technical human capital obsolescence. If, for example, bricklayers at a certain age are no longer able to do their job properly because of persistent back pains, their vocational skills have become worthless.

Atrophy of human capital due to insufficient use of skills is the second category of technical skills obsolescence we can distinguish. This atrophy of human capital could result from longterm unemployment, career interruptions, or from employees' working below their attained level of education. Also, as a result of specialisation, certain knowledge and skills acquired during initial education may get lost during a worker's career.

\section{Economic human capital obsolescence}

As shown in table 1, we can distinguish three types of economic obsolescence of human capital. Firstly, job specific skills obsolescence may occur due to technological or organisational developments in the production process which change the skills demanded for a particular kind of jobs. In that case the skills the workers in that occupation possess are probably no longer sufficient to perform their jobs properly.

A second type of economic skills obsolescence is related to the sector-specific obsolescence due to shifts in the sector structure of employment. In that case workers' skills may still be adequate for their profession, but the demand for their occupation is declining. Shifts in the industry structure of employment can be due to shifts in consumer demand, investments, government purchases and international trade patterns. Due to these demand shifts, part of the workers employed in sectors of industry which face a sharp decline in employment have to find a job in another economic sector in order to remain employed. Skills obsolescence due to shifts in the sector structure of employment is related to the notion that in the global process of specialisation the western economies specialise on the knowledge intensive "high tech' sectors of industry, whereas sectors in which traditionally many low-skilled workers are employed move to the less advanced economies (cf. Wood, 1994).

Finally, economic obsolescence of human capital may be due to firm-specific skills obsolescence. This may occur when workers are laid off in case of a firm closure or reorganisation. When fired, the firm-specific skills of these workers lose their value. 


\section{Measurement of human capital obsolescence}

Given the various kinds of human capital obsolescence it is obvious that the measurement of skills obsolescence is far from straightforward. Whereas the technical obsolescence of human capital is related to the actual deterioration of the skills of a person, economic obsolescence refers to the decreasing market value of particular skills. Furthermore, it should be noted that skills obsolescence can become manifest in several ways:

- unemployment;

- degradation to lower skilled jobs;

- lower wages;

- problems to fulfil one's job properly.

Moreover, at the firm level the depreciation of the human capital of the workforce of a firm can become manifest in higher unit costs of production (Darr et al., 1995).

Four major forms of measuring human capital obsolescence can be distinguished:1

I. objective methods: testing the deterioration of the human capital workers possess.

II. subjective methods: asking workers (and/or their employers) if they face obsolescence of their human capital.

III. measurement of productivity: wages.

IV. measurement of the probability to become unemployed or to withdraw from the labour market.

The first two methods are direct methods to measure skills obsolescence, whereas the last two methods measure the obsolescence of human capital indirectly by indicating the expected effects of skills obsolescence.

The four methods of measuring human capital obsolescence are related to different scientific disciplines. In the psychological literature there are studies that measure the obsolescence of human capital by testing the deterioration of a worker's cognitive skills, either using a recall test or a recognition test (Arthur et al., 1998). It is obvious that these studies only refer to the technical obsolescence of human capital. Bailey (1989) shows how effective experiments in which individuals have to work at repetitive tasks can be applied for testing the wear of skills acquired by learning by doing, whereas Bosma et al. (2003) analyse the deterioration of various cognitive skills (memory, speed and general cognitive status) between two points of measurement in a longitudinal study on age-related 'cognitive decline'.

1. De Grip \& Van Loo (2002) also mention a more indirect measure of human capital obsolescence: the rate of innovations in a particular field of expertise. 
In the economic and sociological literature there are also some studies that measure human capital obsolescence by means of workers' self-assessments in a questionnaire (Blechinger \& Pfeiffer (2000), Van Loo et al. (2001) and Allen \& Van der Velden, 2002). Although different questions are used, all studies more or less focus on job-specific human capital obsolescence. 2

Most prominent in economic literature is the measurement of human capital obsolescence by means of the workers' wages, building on the earning profiles framework that the human capital literature offers (e.g. Mincer \& Ofek, 1982; Neuman \& Weiss, 1995; Jacobson et al., 1993). However, several studies rely on one of the other ways of measurement. Van Loo et al. (2001) use the flow from employment to unemployment or non-participation as an indicator of human capital obsolescence. In a similar way, Allen \& De Grip (2004) use the probability of labour market withdrawal as an indicator of human capital obsolescence.

Actually, all four measures have their restrictions. The first method is obviously the best one to measure the technical obsolescence of a worker's human capital. However, it can not be used for measuring economic skills obsolescence. Moreover, it should be noted that although this method measures the existence of human capital obsolescence directly, it does not indicate whether this skills obsolescence negatively affects a worker's productivity in the job or the probability to remain employed.

The second method can measure both technical and economic skills obsolescence. Van Loo et al. (2001) state that it may be a disadvantage of this measure of human capital obsolescence that it fails to take into account obsolescence which is not perceived by the employees themselves. Individual workers may be myopic when they are not aware of the future impact of technological and organizational innovations that have not yet been introduced in the firm where they work. On the other hand, workers who are employed in very dynamic firms may have the continuous feeling that they cope with skills obsolescence, although in practice this will not harm their future labour market participation or productivity, as they will probably learn the new skills in due time (cf. Allen \& De Grip, 2004). Also employers or managers may be biased when they judge the skills obsolescence of the employees they manage. On the one hand, they will underestimate the skills obsolescence of their subordinates, when workers can hide their lack of competence for their manager, because the latter is not able to monitor the workers directly, or because the manager lacks the professional or idiosyncratic skills that are needed in the jobs of his or her subordinates (cf. Borghans et al., 2000). However, a subjective measure of skills obsolescence may also have the advantage that it reveals obsolescence which is not reflected in workers' earnings due to internal labour markets regulations or other institutions that cause wage rigidity.

The two indirect methods have the advantage that they measure the labour market effects of skills obsolescence that are the main concern on human capital obsolescence in a knowledge economy: a lower productivity or a lower labour market participation. However, when the obsolescence of human capital is measured by experience-earnings profiles (e.g.

2. In Allen \& Van der Velden (2002) the scope is implicitly somewhat broader. 
Neuman \& Weiss, 1995), the obsolescence of workers' human capital may be underestimated when workers' returns to their human capital are 'backloaded' towards the end of their careers to ensure their loyalty to the firm (Lazear, 1979). The same holds when there are downward wage rigidities, or barriers to downward job mobility ('demotion'3).

Oppositely, the occurrence of human capital obsolescence may be overestimated when it is measured by workers' probability to become unemployed or to withdraw from the labour market, as it may be disputable whether a lower labour market participation for a particular group of workers is really due to the obsolescence of workers' human capital. The probability to become unemployment is of course also related to the existence of wage rigidities, barriers to demotion, the so-called replacement rate (i.e. the ratio between social security benefits and a worker's current wage) and additional payments of the previous employer in case of long-term unemployment of older workers. Moreover, the labour market withdrawal of workers that face skills obsolescence will be highly related to the benefits of the various institutional routes of labour market withdrawal,4 such as early pensioning schemes and social security schemes on disablement. It should be noted, however, that the existence of early pensioning schemes for particular professions may be highly related to the risks of skills obsolescence in the profession. This particularly holds for professions, such as firemen, in which workers have high risks of technical skill obsolescence due to the physical requirements for an adequate performance in the job.

Although being an indirect method to measure human capital obsolesce, the probability that a worker withdraws form the labour market has the advantage that it measures the effects of skill obsolescence in the context of the prevailing labour market institutions. In this way the probability of labour market withdrawal measures workers' revealed human capital obsolescence, indicating that the utility of not participating in the labour market outweighs the utility of remaining employed. Obviously this is the core of the debate on the relevance of maintaining workers' productive potential in the knowledge economy.

\section{Evidence of human capital obsolescence}

In this section I will discuss some empirical studies that provide evidence on the relevance of the various possible causes of human capital obsolescence that were discussed in section 2.5 For each study it will also be indicated which of the methods to measure skills obsolescence have been used.

3. Cf. Grossberg \& Sicilian (1999) who show that indirect methods of proxying training with wage growth can be misleading as they fail to distinguish whether wage growth results from training or is a result of the wage determination process.

4. Givord \& Maurin (2003) attempt to separate the effects of institutional changes from the effects of new technologies on involuntary job loss.

5. The overview of studies is not meant to be extensive, but will focus on some characteristic studies on the various categories of human capital obsolescence. 


\subsection{Technical obsolescence}

Wear

Using cross-section data on the Dutch working population, Van Loo, De Grip \& De Steur (2001) found that both physically and mentally demanding working conditions increase the risk of wear, which they measure as the probability that a worker withdraws from the workplace by means of long-term job related sick leave. The latter is indicated by the workers themselves (i.e. a specific form of Method II). The authors choose for this measure of wear because it is truly related to the job, which does not hold for alternative measures, such as work disability or job mobility. Due to the multicollinearity between several specific working conditions, the authors included three clusters of related working conditions in a binomial logit analysis on the probability of long-term job-related sick leave: (1) use of strength, noise, draft, unpleasant temperature, (2) mentally demanding working conditions (3) repetition of the same simple tasks. All three working conditions were found to have significant positive effects on the probability of long-term job-related sick leave.

\section{Atrophy}

On the basis of a meta-analysis from the psychological literature on skill decay and retention (all using Method 1), Arthur et al. (1998) conclude that there is substantial skills obsolescence when skills are not practiced or used. Krahn \& Lowe (1997) analysed the atrophy of skills of workers with long tenures in a job with limited literacy requirements on literacy loss over time (Method I). They found that working in an environment with limited complexity leads to skill loss through atrophy. Bosma et al. (2003) found that the low prevalence of mental stimuli and challenges at work' for many low-skilled workers accelerates cognitive decline to a large extent (Method I). As mentioned in the previous section, all these studies measure skills obsolescence directly, either using recall tests or recognition tests, but are not conclusive on the impact of this obsolescence on a worker's labour market position.

In a panel study on the Dutch working population in the age of 40-62, Allen \& De Grip (2004) found that workers with longer job tenures have a higher risk to lose their job (Method IV). As the authors control for a worker's age, this result can not be attributed to life-cycle effects. Whereas they found a negative linear effect of job tenure, the quadratic effect of job tenure on the risk of loss of work was positive. These results show that when workers are employed in the same job for more than 19 years, they suffer from a 'concentration of experience' that makes it difficult to maintain their position in the labour market. The depreciation of their human capital then outweighs the positive effect of experience on their productivity. An interesting finding in the study of Allen \& De Grip is that the effect of job tenure and tenure squared on training participation show a mirror image. On average after a tenure of 13 years, workers' participation in training falls. Together these results show that when workers with long job tenures decrease their efforts to keep their skills up-to-date, this is an early indicator of job loss due to a concentration of experience. As mentioned in section 3 , 
measuring human capital obsolescence by means of the probability that workers withdraw from the labour market, will be related to the benefits of the various institutional routes of labour market withdrawal. The labour market withdrawal measured in the study of Allen \& De Grip will therefore be related to the prevailing institutional routes of labour market exit in the Netherlands, and will therefore not necessarily hold for other countries.

Several authors analyzed the atrophy caused by career interruptions and periods of unemployment. De Grip \& Van Loo (2002) give an extensive overview of these studies that all focus on the effect of career interruptions on workers' wages (Method III). All studies find that time out from work has a substantial negative effect on wages. Mincer \& Ofek (1982) distinguish three ways in which a career interruption may cause obsolescence of human capital: (1) the atrophy of human capital due to non-use, (2) missing experience or the interruption in the accumulation of human capital, and (3) skill obsolescence induced by the diffusion of technical and organizational innovations. The latter indicates that career interruptions may heavily affect the obsolescence of the human capital of workers who are employed in a segment of the labour market with high risks of economic skill obsolescence (McDowell, 1982).6

Using longitudinal panel data on married women in the US, Mincer \& Ofek found that real wages at re-entry are, indeed, lower than at the moment of labour market withdrawal, whereas the decline in wages is greater, the longer the career interruption. However, they also found a relatively rapid wage growth in the years after the return to work. Several other studies confirm the findings of Mincer \& Ofek for other countries.

It should be noted, however, that when workers, after a period of unemployment find a new job in another firm or in another sector of industry, the lower wage they earn is not necessarily due to atrophy of their skills, as these workers also face the economic obsolescence of their firm-specific or sector-specific human capital (e.g. Jacobson, LaLonde \& Sullivan, 1993 and Neal, 1995).7 In a study on the effects of unemployment among British male workers on their earnings after re-employment, Gregory \& Jukes (2001) try to relate their findings to the atrophy of workers' skills as well as to the loss of firm-specific human capital. Moreover, they argue that workers' income loss after a period of unemployment can be due to the negative signal of both incidence and duration of unemployment. Although Gregory \& Jukes do not strictly test competing hypotheses from these various theoretical points of view, their finding that a longer duration of the unemployment spell increases workers' wage loss after re-employment considerably, indicates the depreciation of workers' skills due to atrophy. As subsequent continuous employment does not reduce the earnings loss related to unemployment duration in the longer run, there is no evidence for the alternative explanation that the income loss is due to the negative signal of long-term unemployment.

6. This study will be discussed below.

7. This firm-specific and sector-specific human capital obsolescence will be discussed at the end of this section. 


\subsection{Economic obsolescence}

\section{Technological and organizational change}

As mentioned in section 2, economic skills obsolescence may occur due to technological or organisational innovations in the production process that change the skills demanded for a particular kind of jobs. Using data on the Jewish, male, married, full time workers from the Israeli census, Neuman \& Weiss (1995) indeed found that particularly high-skilled workers who are employed in high-tech sectors may suffer from the obsolescence of their human capital, as indicated by the effect of experience on workers' wages (Method III). In the earning equation they estimated, they found that the interaction term on workers' level of education and experience has a negative effect on workers' earnings, which indicates that high-skilled workers are most affected by skill obsolescence. Moreover, they divided the various sectors of industry in high-tech sectors and low-tech firms. This enables them to test whether the interaction effect between workers' level of education, work experience and being employed in a high-tech sector has an additional negative effect on workers' earnings. The results of their analysis confirm this expectation, indicating that the returns to education depreciate faster in high-tech sectors of industry.

Although the distinction between high and low-tech industry is obviously important for indicating the extent workers may face skill obsolescence, there probably also are substantial differences in the durability of human capital in the various fields of expertise. McDowell (1982) found that knowledge in physics and chemistry becomes more rapidly obsolete than in humanities. He measured the rate of human capital obsolescence for seven academic disciplines by the age profile of cited works: the proportion of total citations that were published within the five years preceding the year of citation. McDowell found that particularly physics and chemistry are characterized by rapid obsolescence, whereas in sociology and psychology and particularly in history and English knowledge depreciates much more slowly. Being a very indirect measure of skill obsolescence, McDowell's method of measuring the obsolescence of knowledge is not included in the typology given in section 2 (see footnote 1).

MacDonald \& Weisbach (2004) founded the empirical findings of Neuman \& Weiss in a theoretical model in which older workers become more productive by building up experience with the technology they learned at school. However, youngsters make human capital investments that are specific to the current technology, while older workers do not reinvest in this new technology. As technology evolves, the value of the human capital is eroded, especially when experience effects are small compared to the impact of new technology on workers' productivity. In this sense, one can distinguish between experience-dominated and technology-dominated sectors of industry. In the latter sectors, older workers turn into "hasbeens", leading to negatively sloped within-occupation age-earning profiles.

However, opposite to the findings of Neuman \& Weiss, Weinberg (2002) found that new technologies may also complement the existing skills of the workers, which means that having experience of working with old vintages of a technology may improve workers' ability 
to use a new technology. Weinberg analyzed the development of the returns to workers' potential experience in the United States from 1959-1997 (Method III). He found different results for male high school graduates and male college graduates. The increase in the returns to experience for high school graduates from the 1980s is consistent with the idea that experienced workers have been the ones who adopted new technologies. However, for male college graduates there has not been a trend in the returns to experience. This suggests that more experienced college graduates suffer from skill obsolescence due to the introduction of new technologies. From these mixed findings, Weinberg concludes that it is a priori unclear whether the skills of older workers are outdated at a faster pace than those of younger workers by new vintages of IT. It should be noted, however, that the returns to experience for both high school and college graduates may be overestimated, because experienced workers whose skills have been depreciated may have left the workforce.

Bartel \& Sicherman (1993) is one of the studies on human capital obsolescence that focus on labour market participation, instead of wages (i.e. Method IV). In their study on US workers in the age of 45-59, they showed that it is unexpected technology shocks that induce skill obsolescence among older workers, measured in terms of a higher probability of retirement. On the other hand, a more continuous flow of gradual changes in the skills demanded due to technological developments stimulates workers to invest more in additional training, which reduces the risk that their human capital becomes obsolete. Therefore, these workers tend to retire later. Bartel \& Sicherman measure unexpected technology shocks at the sector level, as the deviation from the industry-specific average rate of total factor production growth in the previous ten years divided by its standard deviation. Moreover, they are not able to measure training participation at the individual level. Instead they use occupational means, measured at one point in time. As no adjustment is made for these cluster effects, the significance of the relevant coefficients is probably overestimated (cf. Moulton, 1986). Moreover, workers change occupations during their careers which further reduces the correlation between the training variable used and individuals' real investment in training.

From the same perspective, Friedberg (2003) analysed the relation between computer use and retirement on US data. She found that workers aged 50-62 who use a computer are less often retired four years later than similar workers that do not use a computer. However, this may not only be due to the postponement of retirement by computer users, but also because workers who plan later retirement more often decide to acquire computer skills. Friedberg used an instrumental variables approach to sort out this interaction. In this analysis she instrumented workers' computer use by the average computer use in the same occupation and industry. The results of this IV analysis show that the effect of computer use on delaying retirement remains large. This result shows the relation between the efforts workers are willing to make to prevent human capital obsolescence, and the occurrence of skills obsolescence. In this sense the result is similar to the finding of Bartel \& Sicherman in the case of more gradual changes in the skills demanded due to technological change.

Givord \& Maurin (2004) attempted to separate the effects of institutional changes from the effects of new technologies on involuntary job loss. Controlling for macro-economic 
development and dummy variables for periods in which labour laws were less and more restrictive, they found that the rise in involuntary job loss rates in France in the 1990s was significantly higher in sectors of industry with the largest share of internet users or R\&D workers. Although their study is related to other studies discussed in this section that use Method IV to measure skills obsolescence, it is difficult to interpret the results of Givord \& Maurin in terms of skills obsolescence. First, there is a negative effect of workers' age on job loss risks. Second, the decline in job security in the 1990s only refers to workers with tenures of less than two years.

Using linked employer-employee data on French manufacturing firms, Aubert, Caroli \& Roger (2004) found that the diffusion of information technology (IT) and the related organizational changes are a major cause of skill obsolescence, which they measure in terms of the effects of technological and organizational change on the wage bill shares and the employment inflows and outflows of the various age groups in three occupational sectors (managers, clerks and blue colour workers) (Method IV). They found that new technologies reduce the hiring opportunities for older workers, whereas they increase the hiring of younger workers. Oppositely, organisational innovations mainly increase the outflow of older workers and decrease the outflow of younger workers. It should be noted that Aubert et al. were not able to use panel data. Moreover, they did not succeed to find adequate instrumental variables. Therefore they were not able to analyse the causality between innovation and the inflow and outflow of workers of different age groups properly.

Allen \& De Grip (2004) did not find a significant effect of IT use and organizational change on the probability to become unemployed or non-participating in the labour market two years later (Method IV). They found, however, that workers who perceive skill obsolescence in a previous period (Method II) participate more often in training and are willing to enlarge the 'learning potential' of their job by performing tasks that are not closely related to their own job description. From these findings Allen \& De Grip conclude that both employers and workers may respond or anticipate on the effects of technological and organizational change on the skills demanded in the job, by greater investments in training and learning on-the-job. The latter means that workers who are employed in a dynamic job more or less continuously face skill obsolescence. However, the skills obsolescence perceived by the worker is a bad predictor of any adverse effects of this obsolescence on workers' probability to remain employed in the next two years.

The conclusions of Allen \& De Grip are in line with both the findings of Bartel \& Sicherman in the case of gradual technological innovations, and the findings of Friedberg on the effect of computer use on (delaying) retirement. It should be noted that the study of Allen \& De Grip differs from the study of Aubert et al. in many respects. First, the analysis of Allen \& De Grip refers to individual workers, instead of firms. Second, Allen \& De Grip uses the panel character of their data by analyzing the effects of technological and organizational change on outcomes that are measured two years later. Third, Allen \& De Grip includes many more controls, particularly at the individual level. 
Van Loo, De Grip \& De Steur (2001) analyse whether skills obsolescence is related to the shifts in the sector structure of employment. Combining Dutch cross-section data on individual workers with aggregate data on the shifts in the structure of employment, they found that neither shifts in the sector structure, nor shifts in the occupational structure of employment increase workers' risk to become unemployed or non-participating (Method IV). However, changes in the demand for various types of education do increase the risk of becoming unemployed or non-participating. Van Loo et al. (2001) also found that both workers' willingness to participate in training and their willingness to be functionally flexible decrease the risk that they become unemployed or withdraw from the labour market.

Van Loo et al. (2001) also analysed whether the job mobility of individual workers to (1) a similar job in another firm in the same sector, (2) a different job in a different firm in the same sector and (3) a different job in a different firm in a different sector of industry worsens the suitability of the worker's skills for their job. The latter is measured by asking it to the workers themselves (Method II). The estimation results of Van Loo et al. confirm their hypotheses, indicating that the mobility of workers induces the obsolescence of the firm-specific, occupation-specific and sector-specific skills that were relevant for their previous job. It should be noted, however, that the authors did not control for career mobility towards higher level jobs, which makes it questionable to interpret the results as indications of skills obsolescence.

In a theoretical paper, Wasmer (2003) argued that the different labour market institutions in the US and Europe have different effects on the risks of human capital obsolescence. Due to the restricted employment protection in the US, workers invest in general human capital, whereas the European labour market institutions favour investments in firm-specific human capital. For this reason job tenures in Europe are longer than in the US. However, when these jobs are destroyed at some time, workers' firm-specific human capital becomes obsolete, which will make it very difficult for these workers to hold a position in the labour market. Whereas the European firm-specific human capital model is superior tot the US model in steady-state situations, the general human capital model of the US is superior in a more volatile environment.

Several studies show that mass layoffs cause large losses of firm-specific human capital, even when the local labour market is doing well. Most of these studies measure the obsolescence of workers' firm-specific or sector-specific human capital by the effect on postdisplacement wages (Method III). Combining unemployment insurance data with firm data, Jacobson et al. (1993) found that workers who were involved in mass layoffs face wage losses up to 25 percent of pre-displacement wages. Neal (1995) and Kletzer (1998) found that displaced workers who found a job in another sector of industry face the obsolescence of their sector-specific human capital, as indicated by the fact that their wage is lower than the wage of comparable workers who stayed in the industry (Method III). Moreover, for more experienced workers who switch industries following displacement the wage loss is larger (Neal, 1995). 
As is shown by several studies the divergence in the distribution of income losses of displaced workers is large. In his study on the displaced workers of the former Dutch aircraft company Fokker, Kriechel (2003) found that one year after the bankruptcy, a quarter of the displaced workers were still not employed in a new job. Apart from the workers who were unemployed, a large group of workers withdrew from the labour market (Method IV). For the workers who found a new job the wage loss is related to the occupational group in which the workers were employed at Fokker, ranging from 11.9 percent for administrative workers to 7.1 percent for R\&D workers and 6.3 percent for production workers (Method III).

\section{Sectors of industry with highest risks of human capital obsolescence}

After the literature review in the last section, I will in this section try to indicate in which sectors of industry workers potentially face the highest risks of a particular kind of human capital obsolescence.8 As shown in the previous section, this does not necessarily mean that workers actually run the risk to be faced with skill obsolescence at some time in their careers, as both employers and workers often respond or anticipate on these risks. However, in section $7 \mathrm{I}$ will use these indicators of the potential risks of human capital obsolescence in each economic sector as a point of reference, when I discuss the training participation of the workers in the various sectors of industry. The data presented here refer to the Netherlands but will mostly be indicative for other EU countries. As this section only pretends to be indicative on differences in the relevance of human capital obsolescence between sectors of industry, I will not cover all the plausible causes of human capital that were distinguished in section 2 .

\section{Technical obsolescence}

As mentioned in section 2, the depreciation of human capital may be related to physically or mentally heavy working conditions that make it in the long run impossible to remain employed in the job. In that case workers' occupation-specific human capital will lose its value. Figure 1 shows the extent to which workers in the various sectors of industry that regularly face physically heavy working conditions in their job. The indicator shown is an index based on three physically heavy working conditions: to have to apply strength, to work in a noisy workplace and to work with vibrating tools or equipment. The figure shows that workers employed in the construction sector most often face physically heavy working conditions, followed by those employed in the engineering industry and the agricultural sector. However, the engineering industry succeeded in lowering the physical strain of its employees between 2000 and 2001/2002. In general, working conditions in the service sectors are physically less heavy than the working conditions in manufacturing and the agricultural sector. However, also the jobs of nurses and health care assistants are physically heavy jobs.

8. Of course there are usually large differences between the various occupations in a sector of industry. More details on the risks of skill obsolescence by occupational group and educational background of workers can be found in ROA (2004). 
Figure 1

Frequent physically heavy working conditions by sector of industry in the Netherlands

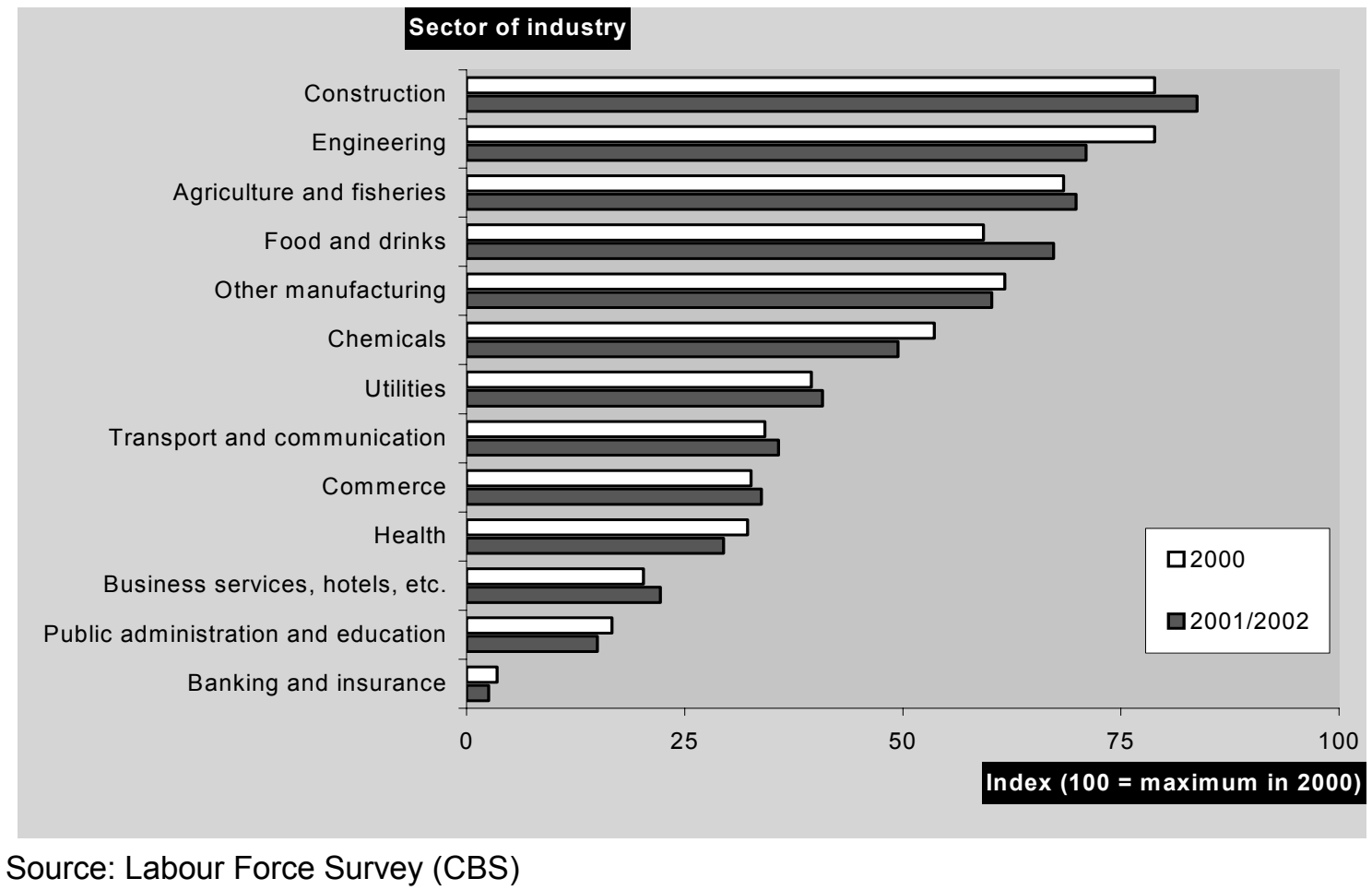

Figure 2

Frequent mentally heavy working conditions by sector of industry in the Netherlands

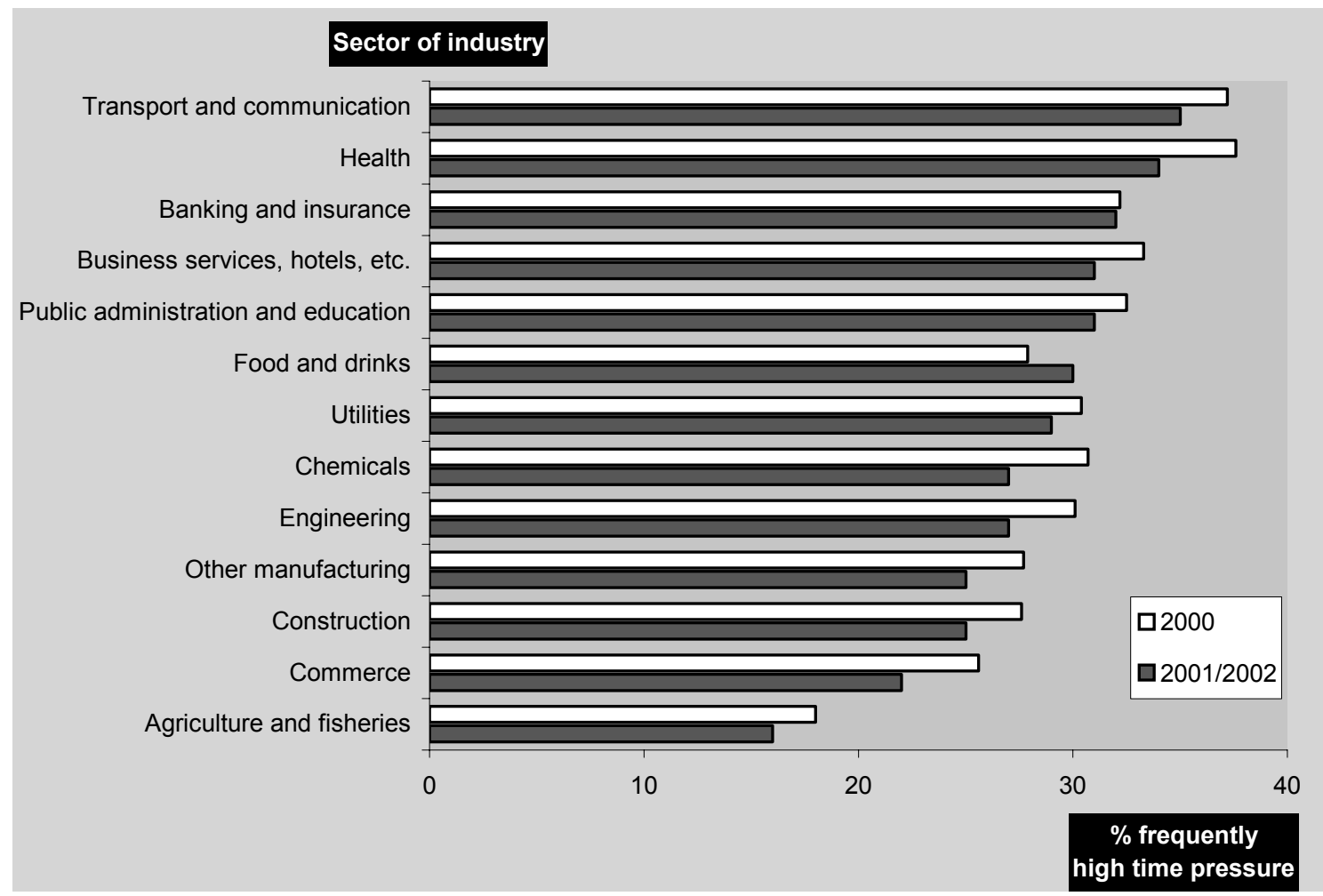

Source: Labour Force Survey (CBS) 
Figure 2 gives an overview of the mental strain of the workforce employed in the various sectors of industry. Actually, the indicator used measures whether workers frequently work under time pressure. The figure shows that in 2001 and 2002 on average more than $30 \%$ of the workers employed in the transport and communication sector and the health sector frequently work under time pressure. In several other sectors, more than a quarter of the employees frequently work under time pressure. In general, particularly high-skilled workers, such as managers, journalists and lawyers, work under high time pressure. This does not hold, however, for the transport sector, where aircraft, ship as well as train personnel frequently work under time pressure. Also workers employed in health care occupations frequently work under high time pressure. As the latter also face physically heavy working conditions, they are quite at risk due to a wear of their competencies.

\section{Economic obsolescence}

Due to technological or organisational innovations of the production process the skills demanded for a particular kind of jobs may change. In that case the skills the workers in that occupation possess are probably no longer sufficient to perform their jobs properly.9 It should be noted, however, that several studies discussed in the previous section, found that technological innovations does not threaten workers' employability, as it will increase further investments in their human capital.10

Figure 3 indicates to what extent the jobs of the workers in the various sectors of industry are affected by technological and organisational change. The scores are based on an unweighted index of different indicators on: changes in products or services produced, technical innovations of the production process, the percentage of workers affected by these changes, diffusion of information technology and reorganisations.

The figure shows that the greatest effects of technological and organizational change do not occur in the high-tech sectors, as assumed by e.g. Neuman \& Weiss, 1995. It is the workers employed in the banking and insurance sector who have the largest score on the technological and organizational change indicator. In banks and insurance companies radical changes in the mode of production have taken place and affected almost all employees in this sector. Moreover, the diffusion of information technology in this sector is the highest from all sectors of industry.

Also the sector public administration and education has a high score on the technological and organizational change index, due to the extensive diffusion of information technology. Moreover, in this sector the percentage of organizations that introduce substantial organizational changes is the highest from all sectors of industry. All these developments have a substantial impact on the job content of most of the employees in this sector.

9. As discussed in the previous section, Weinberg (2002) found that new technologies may, however, also complement the existing skills of more experienced workers.

10. In section 7 we will show workers' training participation in the various sectors of industry. 
Figure 3

Technological and organizational change by sector of industry in the Netherlands, 1999-2001

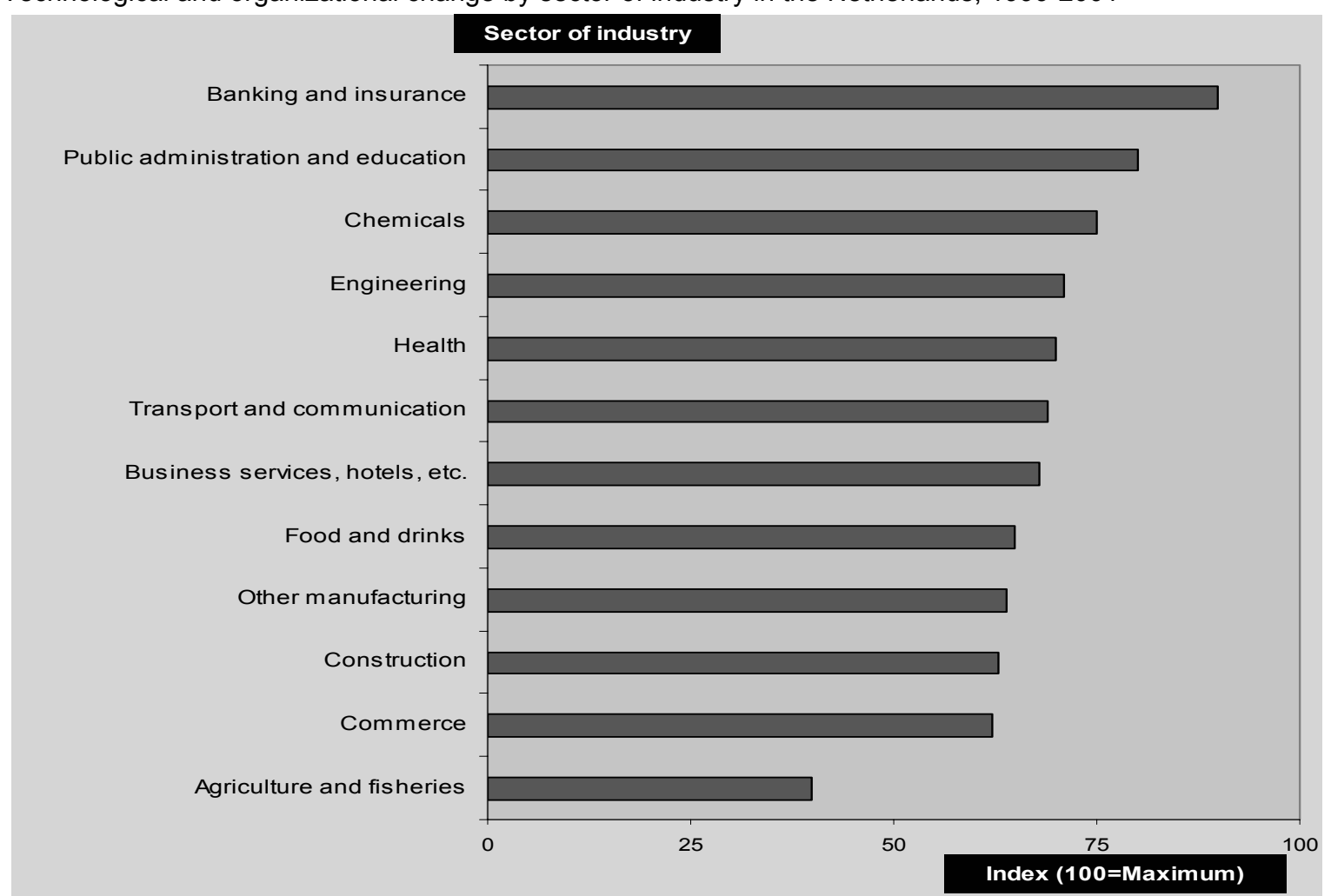

Source: Labour Force Survey (CBS)

However, also the more traditional high-tech manufacturing sectors of industry - chemicals and engineering - have a relatively high score on the technological and organizational change indicator. In these two sectors of industry many firms keep on introducing technical innovations of the production process and new products. However, organizational change is less prominent in these two high-tech sectors.

As mentioned, shifts in the sector structure of employment may cause a second type of economic skills obsolescence, when workers are no longer able to hold their position in the sector of industry where they were employed. When employment in a particular segment of the labour market shrinks, the demand for the skills of the workers declines. Table 2 shows that in the Netherlands the agricultural sector as well as most sectors of industry in manufacturing were facing a decrease in employment in the last few years. The labour market forecasts of the Dutch Research Centre for Education and Labour Market (ROA) show similar expectation for next few years. Moreover, the forecasts indicate a decrease of employment in the construction sector and the sector transport and communication. 
Table 2

Development of employment in 1998-2002 and employment forecasts for 2003-2008 by sector of industry in the Netherlands

\begin{tabular}{lcc}
\hline Sector of industry & $\begin{array}{c}1998-2002 \\
\%\end{array}$ & $\begin{array}{c}2003-2008 \\
\%\end{array}$ \\
\hline Agriculture and fisheries & & -2.6 \\
Food and drinks & -2.5 & -0.2 \\
Chemicals & -2.1 & -1.3 \\
Engineering & -2.2 & -1.9 \\
Other manufacturing & 0.0 & -1.2 \\
Utilities & 1.3 & 0.4 \\
Construction & -2.1 & -0.6 \\
Commerce & 2.1 & 0.4 \\
Transport and communication & 1.1 & -1.0 \\
Bank and insurance & 1.3 & 1.3 \\
Business services. hotels, etc. & 2.1 & 0.6 \\
Health & 5.0 & 1.1 \\
Public administration and education & 3.5 & 1.0 \\
& 2.5 & 0.2 \\
Total & & 0.2 \\
\hline
\end{tabular}

Source: ROA, CPB and Statistics Netherlands

\section{Life-long learning}

The various potential risks of skill obsolescence address the current need for life-long learning. This holds the more because of the greying working populations in the European Union. Table 3 gives a typology of the kind of training or on-the job learning that could be a remedy for the various types of skills obsolescence, distinguished in Section 2. When the human capital of workers depreciates due to physical or mental wear, retraining for another occupation with less demanding working conditions will be required. There may be quite some underinvestment in this retraining, as both firms and workers have little incentives to invest in this kind of training, because of the existing facilities for early labour market exit due to disablement. However, in an earlier phase workers could benefit from training courses that enable them to better cope with the physically or mentally demanding working conditions in their job.

In case of atrophy due to a career interruption or a long tenure in a job with a low learning potential, refresher courses could be a remedy, i.e. a course in which a review is given of the knowledge and skills that have gone lost. However, if the skill-gap with the skills demanded in the job where someone was used to work has become too large, retraining for another, probably lower level, occupation may be a solution. 
Table 3

Possible learning remedies for the various types of human capital obsolescence

Type of skills obsolescence

Possible training/learning remedy

Technical human capital obsolescence

- Wear

- Atrophy

Training to cope with demanding working conditions or retraining for another job

Refresher course or retraining

Economic human capital obsolescence

- Job-specific human capital obsolescence

- Skills obsolescence by sectoral employment shifts

- Firm-specific skills obsolescence Learning on-the-job in other firm or retraining

In case of job-specific skill obsolescence the value of the human capital of workers decreases, because the diffusion of technological or organizational innovations changes the skills demanded in the job. Of course, the best way to prevent this kind of skill obsolescence is by learning on-the-job or to enrol in training that focuses on the new skills demanded. As discussed in Section 2, this kind of life-long learning activities will usually take place when people work in a continuously dynamic job with a high learning potential. Only in case of unexpected shocks in the skills demanded, or large shifts in the skills demanded, further training may be problematic. This will particularly be the case when traditionally low-skilled jobs are upgraded to jobs that require a much higher skill level.

When workers face skills obsolescence because they have been displaced due to sectoral shifts in employment, they have to be retrained for a job in another economic sector. However, there may be severe underinvestment in this kind of retraining. Neither the firms that stop producing, nor the firms that have to lay-off part of their workforce, usually have the funding for retraining their displaced workforce for quite different jobs. In the Netherlands also the sectoral training funds usually have no incentive for retraining workers for another sector of industry, even when it is co-financed by the available European Social Fund subsidies 11 (ROA, 2004).

When displaced workers are able to find a similar job in another firm in the same sector of industry they will (only) face firm-specific skills obsolescence. These workers will usually learn the firm-specific skills in the new firm to a large extent on-the-job, although this may be supplemented by formal retraining.

11. In the Netherlands part of the ESF 3 subsidies aim to prevent that workers who are at risk will lose their job. 


\section{Training participation and risks of human capital obsolescence in the Netherlands}

In this section I will briefly discuss the training participation in the various sectors of industry in the Netherlands, with a reference to the various risks of human capital obsolescence the workforce in the sector concerned faces. Table 4 shows the extent to which the workers in the various sectors of industry in the Netherlands participate in training. More in general the table shows that there has been a sharp decline of training participation in most sectors of industry due to the recent economic recession. This particularly holds for chemicals, other manufacturing and commerce.

The table shows that participation in training is relatively low in the agriculture and fisheries sector, given the risks of wear due to the physically demanding working conditions, and the risk of skill obsolescence due to the substantial decrease of employment.12 In the food and drinks sector, however, there has been a substantial increase of training participation. This sector often uses European Social Fund subsidies for financing training courses.

Table 4

Training participation by sector of industry in the Netherlands

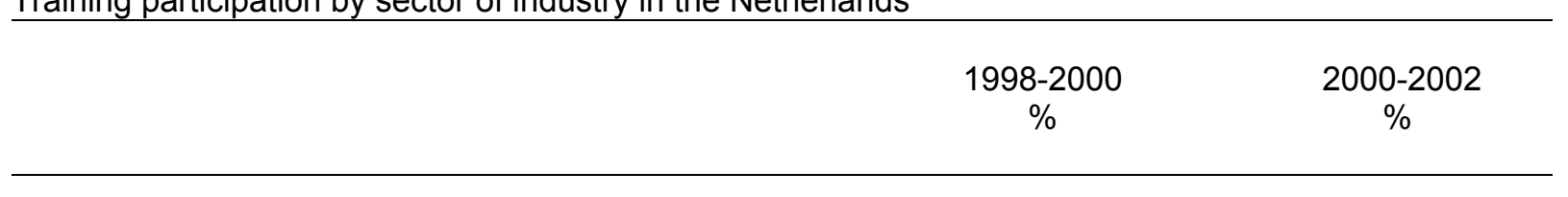

Agriculture and fisheries

Food and drinks

$43 \quad 57$

Chemicals

59

Engineering

Other manufacturing

35

Utilities

Construction

Commerce

Transport and communication

Bank and insurance

Business services, hotels, etc.

Public administration and education

Source: Labour Supply Survey (OSA)

The decline in training participation in chemicals is remarkable, given the relatively large risks of skills obsolescence in this sector of industry due to the rapid diffusion of technological and organizational innovations and the decline of employment. This indicates that part of the workforce in this sector of industry, which is very sensitive for developments in the business cycle, may face severe risks of losing their jobs due to human capital obsolesce in the long or short run. Also in engineering training participation decreased substantially, although it is still at an average level. However, as the workforce in this sector runs relatively large risks of skills obsolescence due to physically demanding working

12. See ROA (2004) for more details on the risk profiles of each sector of industry. 
conditions, technological and organizational change as well as a decreasing employment, the decreasing training participation might indicate substantial risks of job loss due to skills obsolescence. The sector other manufacturing is of course a rather heterogeneous sector. This may explain that the sector shows moderate risks of skill obsolescence. It is, however, precarious that in this sector training participation decreased to a very low level.

The utilities sector shows the highest rates of training participation. Although we could not construct an indicator of the degree of technological and organizational change for this sector, there is ample evidence that there is substantial organizational change in this sector that is shifting from the public sector to the market sector. However, this transformation seems to be facilitated by high rates of training participation.

Also in the construction sector training participation is above average. As mentioned, the workers in the construction sector face the highest risks of wear due to the physically heavy working conditions in their jobs. Although $20 \%$ of the workers in the sector took courses related to the physically heavy working conditions or the safety at work, it is obvious that still many construction workers leave the labour market at a rather early age, when they are no longer physically able to do their job. Therefore, the construction sector is particularly in need of retraining trajectories that enable older workers to find a less demanding job in another sector of industry.

In the commerce sector training participation decreased to a very low level. However, the often low-skilled workers in the sector do not face high risks of skill obsolescence. This indicates the low-skills equilibrium of employment in this economic sector (cf. Wilson \& Hogarth, 2003). Also in the sector transport and communication training participation is relatively low. As many workers in this sector face mentally heavy working conditions due to time pressure, whereas there is also substantial technological and organizational change and employment is expected to decrease in the near future, workers in this sector face substantial risks of skills obsolescence.

Training participation in banking and insurances is traditionally at a high level. However, there has been a substantial decline in training participation. This is precarious because the workers in this sector face the highest risks of human capital obsolescence due to the impact of technological and organizational change. Moreover, many workers in the banking and insurances sector face mentally heavy working conditions. In the sector business services, hotels etc. training participation declined to a relatively low level. Obviously, the sector is too heterogeneous with respect to the skill level of the workforce to get a good grip on the risks of skills obsolescence. However, there are particularly many workers who face mentally heavy working conditions.

In the health sector training participation declined to a level slightly below average. As shown above, the workers in this sector face high risks of wear of skills due to the mentally heavy working conditions. Moreover, there is a relatively high rate of technological and organizational change in the health sector. Furthermore, the workers in the care occupations 
also face physically heavy working conditions. Therefore, particularly the need for retraining the workers who are no longer able to fulfil their health-care job will not be met.

Also in the public administration and education sector training participation declined, although it is still above average. Those employed in this sector particularly need to keep their job-specific skills up-to-date, because of the high rate of technological and organizational change.

\section{Older workers}

It should be noted that in general particularly older workers face the various risk of skills obsolescence. They are not only the ones with the longest tenure in physically or mentally demanding jobs, but they also have the less recent vintage of human capital (Neuman \& Weiss, 1995). Moreover, returns on investment in training of older workers are relatively low, due to the shorter period in which they can benefit from a training investment. Table 5 shows that the training participation of older workers in the Netherlands falls less behind the training participation of prime-aged workers than in other European countries (cf. European Commission, 2003). However, the table also shows that in the recent economic recession training participation of older workers declined much stronger than training participation of younger workers.

Table 5

Training participation in the Netherlands by age group

\begin{tabular}{|c|c|c|}
\hline Age group & $\begin{array}{c}1998-2000 \\
\%\end{array}$ & $\begin{array}{c}2000-2002 \\
\%\end{array}$ \\
\hline $15-25$ years & 40 & 41 \\
\hline $26-35$ years & 52 & 49 \\
\hline $36-45$ years & 56 & 47 \\
\hline $46-55$ years & 52 & 40 \\
\hline $56-65$ years & 45 & 32 \\
\hline
\end{tabular}

Source: Labour Supply Survey (OSA)

\section{Conclusions and policy implications}

As mentioned in the introduction, the risks of human capital obsolescence belong to the heart of the economic challenge of greying knowledge economies. Whereas the greying of the workforce may indicate higher risks of technical human capital obsolescence, the rapid diffusion of technological and organizational change and the related shifts in the structure of employment may indicate high potential risks of economic human capital obsolescence.

Given the relevance of the topic, the literature on human capital obsolescence is remarkably limited. Obviously, this is due to the poor availability of adequate longitudinal data on the stocks of skills embodied in the working population, the shifts in the skills demanded in the 
labour market and detailed information on the participation in training and other learning activities.13 Talking about a knowledge society, it is strange to notice the lack of data on the human capital embodied in the potential working population and the ways in which skills are acquired and deteriorated or losing their value in the labour market.

In the literature on human capital obsolescence different ways of measurement are used. All these measures have their restrictions. Having more information on the shifts in the skills demanded and embodied in the various age-groups of workers will improve measurement. Moreover, economic research in which human capital obsolescence is indirectly measured by means of age-earning profiles or the probability of labour market withdrawal, should be further developed by taking account of the interaction with labour market institutions on remuneration and the various routes of labour market exit (cf. Givord \& Maurin, 2004). As mentioned in section 3,1 think that when studies succeed to relate workers' labour market withdrawal properly to human capital obsolescence in its interaction with labour market institutions affecting early exit from the labour market, research will contribute to our knowledge of maintaining workers' productive potential in the knowledge economy.

Several studies indicate that all kinds of human capital obsolescence distinguished occur in practice. However, due to the limitations in the measurement of skill obsolescence, the results found can often be related to alternative explanations. Obsolescence of human capital might, however, both lower the productivity of the working population (e.g. Neuman \& Weiss, 1995) and lower the labour market participation of workers with obsolete skills (e.g. Van Loo et al., 2001). Human capital obsolescence could therefore cause a slow down of productivity at the firm level as well as the macro level. However, as shown by Allen \& De Grip (2004) technological and organizational change will usually be accompanied by investments in further learning. In as far as the diffusion of technological and organizational innovations causes human capital obsolescence, human capital obsolescence will probably only occur in the case of unexpected radical changes (Bartel \& Sicherman,1993), whereas in general technological and organizational change decreases early exit from the labour market, as these workers continuously invest in lifelong learning.

However, as indicated in section 6, employers as well as workers may have less incentives to invest in training in the case of other causes of potential human capital obsolescence. For instance, when workers face a wear of their skills due to heavy working conditions or substantial shifts in the sector structure of employment, financial incentives to invest in retraining for another job are often lacking. Of course this is highly related to the prevailing institutions that affect the replacement rate in case of unemployment or labour market withdrawal. When workers have opportunities to withdraw from the labour market without substantial wage loss, the net benefits of retraining for another job will be low. It should be noted that the same holds for firms. If firms face few costs when they dismiss workers with obsolete human capital, it will usually be more profitable to recruit younger workers with a more recent vintage of human capital.

13. A positive exception is the British Skills Survey, although this survey lacks longitudinal data. 
In the Netherlands there are training funds in most sectors of industry, which subsidize training investments by means of a levy-grant system. Although, these sector funds play a positive role in encouraging training investments that prevent or diminish job specific skills obsolescence, these training funds also hardly have any incentives to finance the retraining of workers that have to switch to a jobs in another sector of industry (ROA, 2004).

The policy implications from the above conclusions are rather straightforward. First, more investments should be made in developing the statistics on the skills demanded in the labour market, the potential risks of human capital obsolescence, and the acquisition and deterioration of the human capital of the potential working population. This will contribute to the transparency of the labour market dynamics that may cause human capital obsolescence. Moreover, this will encourage and improve the research on the skills demanded in the labour market, human capital obsolescence, and life-long learning. At the moment not only governments are badly informed on the costs and benefits of life-long learning, also individuals often lack the information on the risks of human capital obsolescence they run in the various occupational fields and sectors of industry, and the ways in which they can anticipate or react to these risks. In order to diminish market failure, the labour market transparency in this field should be improved.

Furthermore, public policy in the field of working conditions and social security should be related to public policy in the field of education, career development and continuous vocational training. In a similar way public policy should take account of the interaction between human capital obsolescence and the labour market institutions related to the various routes of labour market exit. Although the 'Lisbon agenda' of the European Council offers a good framework for an integrated view on these different policy fields, there is still a long way to go.

Finally, with respect to the risks of human capital obsolescence as well as the investments in life-long learning, major decisions must be taken on the responsibilities of firms, individual workers and the government. In practice, firms usually take their responsibility to maintain the human capital of their workforce in case of technological and organizational change. On the other hand governments are traditionally heavily involved in the retraining problems related to the human capital obsolescence at the bottom of the labour market, unemployed workers and with respect to particular disadvantaged groups. However, it is probably particularly the individual workers who are often challenged to stay 'employable' in the labour market, for whom a consistent demarcation of their responsibilities for life-long learning is lacking, and proper incentives and financial facilities are missing (cf. SER, 2002). This particularly holds for investments in retraining when workers have to switch to a job in another sector of industry when they can not hold their current job.

\section{References}

Allen J. \& A. De Grip (2004), Skill Obsolescence, Lifelong Learning and Labour Market Participation, mimeo, Research Centre for Education and the Labour Market, Maastricht. 
Allen, J. \& R. van der Velden (2002). When do skills become obsolete, and when does it matter?, in: A. de Grip, J. van Loo and K. Mayhew (Eds.), The Economics of Skills Obsolescence, Research in Labor Economics, vol. 21, JAI Press, 2002, 27-50.

Arthur, W. J., Bennett, W. J., Stanush, P. L., \& McNelly, T. L. (1998). Factors that Influence Skill Decay and Retention: A Quantitative Review and Analysis. Human Performance, 11(1), 57-101.

Aubert, P., E. Caroli \& M. Roger (2004), New Technologies, Workplace Organisation and the Age Structure of the Workforce : Firm-Level Evidence, Paper presented at the MERIT Workshop on Information Technology and New Industry and Labour Market dynamics, Maastricht.

Autor, D.H., L.F. Katz \& A.B. Krueger (1998). Computing Inequality: Have Computers Changed the Labour Market?, Quarterly Journal of Economics, 113, 1055-1089.

Bailey, C. D. (1989), Forgetting and the Learning Curve: A Laboratory Study. Management Science, $35,340-352$.

Bartel, A.P. \& F.R. Lichtenberg (1987). The Comparative Advantage of Educated Workers in Implementing New Technology, Review of Economics and Statistics, 69, 1-11.

Bartel, A.P., \& Sicherman, N. (1993). Technological Change and Retirement Decisions of Older Workers. Journal of Labor Economics, 11, 162-183.

Blechinger, D. \& Pfeiffer, F. (2000). Technological Change and skill Obsolescence: the Case of German apprenticeship Training, in: H. Heijke and J. Muysken (Eds.), Education and Training in a Knowledge-Based Economy, Houndsmill/London: Macmillan, 243-376.

Borghans et al. (2000). Organisatieveranderingen en competentie-ontwikkeling, ROA-R-2000/3, Maastricht.

Borghans, L., P.S. Marey \& B. ter Weel (2003). Information Technology and the Value of Skills: A Systematically Varying Parameter Model Applied to 64 European Regions, mimeo, Maastricht University, Maastricht.

Bosma, H., Boxtel, M.P.J. van, Ponds, R.W.H.M., Houx, P.J.H. \& Jolles, J. (2003). Education and Age-Related Cognitive Decline: The Contribution of Mental Workload. Educational Gerontology, 29, 165-173.

Bresnahan, T.F., E. Brynjolfsson, L.M. Hitt (2002), Information technology, workplace organization and the demand for skilled labor: Firm-level evidence, Quarterly Journal of Economics, 117, 339376.

Caroli, E. \& Van Reenen, J. (2001), Skill Biased Organizational Change? Evidence from a panel of British and French Establishments, Quarterly Journal of Economics, 116, 1449-1492.

Cörvers, F. (1999), The impact of human capital on international competitiveness and trad performance of manufacturing sectors, Maastricht University, Maastricht. (Ph.D. Thesis).

Darr, E. D., L. Argote, \& Epple, D. (1995). The Acquisition, Transfer, and Depreciation of Knowledge in Service Organizations: Productivity in Franchises. Management Science, 41, 1750-1762.

De Grip, A., M. Van Smoorenburg \& L. Borghans (1997). The Dutch Observatory on Employment and Training, ROA-W-1997/2 ${ }^{\mathrm{E}}$, Research Centre for Education and the Labour Market, Maastricht.

De Grip, A. \& J. van Loo (2002). The Economics of Skills Obsolescence: A Review, in: A. de Grip, J. van Loo and K. Mayhew (Eds.), The Economics of Skills Obsolescence, Research in Labor Economics, vol. 21, JAI Press, 2002, 1-26. 
Dubin, S., S., 1972. Obsolescence or Lifelong Education. American Psychologist, 27, 486-498.

European Commission (1993), Growth, competitiveness, employment. The challenges and ways forward to the $21^{\text {st }}$ century, Bulletin of the European Communities. Supplement 6/1993, Office for Official Publications of the European Communities, Luxembourg.

European Commission (2003). Employment in Europe 2003, Brussels.

Friedberg, L. (2003). The Impact of Technological Change on Older Workers: Evidence from Data on Computer Use, Industrial and Labor Relations Review, 56, 511-529.

Givord, P. \& Maurin, E. (2003). Changes in Job Security and Their Causes: An Empirical Analysis for France, 1982-2002, European Economic Review, 48, 595-615.

Givord, P. \& Maurin, E. (2004). Changes in Job Security and their Causes: An Empirical Analysis for France, 1982-2002, European Economic Review, 48, 595-615.

Green, F., Ashton, D., Burchell, B., Davies, B., \& Felstead, A. (2000). Are British Workers Becoming More Skilled? In L. Borghans \& A. De Grip (Eds.), The Overeducated Worker? The Economics of Skill Utilization (pp. 77-106). Cheltenham: Edward Elgar.

Gregory, M. \& Jukes (2001). Unemployment and Subsequent Earnings: Estimating Scarring Among British Men 1984-94, Economic Journal, 111, F 607-F625.

Grossberg, A.J. \& Sicilian, P. (1999). Minimum Wages, On-the-Job Training, and Wage Growth, Southern Economic Journal, 65, 539-556.

Jacobson, L. S., LaLonde, R. J., \& Sullivan, D. G. (1993). Earnings Losses of Displaced Workers. American Economic Review, 83(4), 685-709.

Kletzer, L., 1998. Job Displacement. Journal of Economic Perspectives, 12, 115-136.

Krahn, H., \& G.S. Lowe (1997). Literacy utilization in Canadian Workplaces. Statistics Canada, Ottawa.

Kriechel, B. (2003). Heterogeneity Among Displaced Workers, Ph.D. thesis, Maastricht University, Maastricht.

Lazear, E.P. (1979). Why is there mandatory retirement? Journal of Political Economy, 87, 12611284.

Lindbeck, A., \& Snower, D. (2000). Multi-Task Learning and the Reorganisation of Work, from Tayloristic to Holistic Organization, Journal of Labour Economics, 18, 353-376.

MacDonald \& Weisback (2004). The Economics of Has-beens, Journal of Political Economy, 112, s289-s310.

Machin, S. \& J. van Reenen (1998), Technology and changes in skill structure. Evidence from seven OECD countries, Quarterly Journal of Economics, 113, 245-279.

McDowell, J. M. (1982). Obsolescence of Knowledge and Career Publication Profiles: Some Evidence of Differences among Fields in Costs of Interrupted Careers. American Economic Review, 72, 752-768.

Mincer, J., \& Ofek, H. (1982). Interrupted Work Careers: Depreciaton and Restoration of Human Capital. Journal of Human Resources, 17, 3-24. 
Moulton, B.R. (1986). Random group effects and the precision of regression results, Journal of Econometrics, 32, 385-397.

Neal, D. (1995) Industry-Specific Human Capital: Evidence from Displaced Workers, Journal of Labor Economics, 13, 653-677.

Neuman, S., \& A. Weiss (1995). On the Effects of Schooling Vintage on Experience-Earnings Profiles: Theory and Evidence. European Economic Review, 39, 943-955.

ROA (2004). Werkgelegenheid en Scholing 2003(Employment and training 2003), ROA-R-2004/1, Maastricht.

Romer, P.M. (1990). Endogenous Technological Change, Journal of Political Economy, 98, s71-s102.

SER (2002).Het nieuwe leren (Advisory report on lifelong learning in the knowledge-based economy), Advies 02/10, The Hague.

Van Loo, J., De Grip, A., \& De Steur, M. (2001). Skills Obsolescence, Causes and Cures. International Journal of Manpower, 22, 121-137.

Wasmer, E. (2003). Interpreting European and US Labour Market Differences: The Specificity of Human Capital Investments, Centre for Economic Policy Research, Discussion Paper 3780, London.

Weinberg, B.A. (2002). New Technologies, Skills Obsolescence, and Skill Complementarity, in: De Grip, A., J. van Loo and K. Mayhew (Eds.), The Economics of Skills Obsolescence, Research in Labor Economics, vol 21, Amsterdam/Boston: JAI Press, 101-118.

Wood, A. (1994). North-South Trade, Employment and Inequality: Changing Fortunes in a Skill Driven World, Clarendon Press, Oxford. 